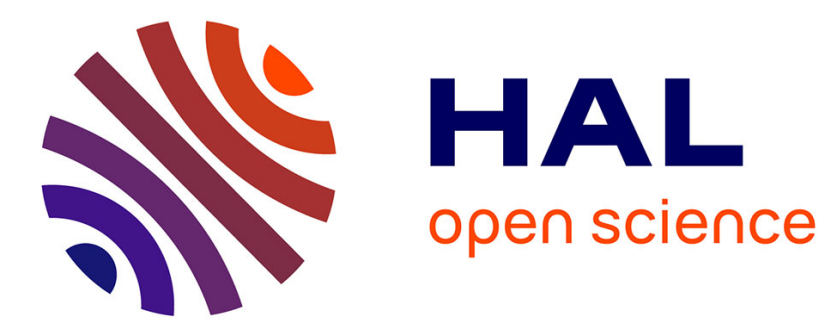

\title{
Upper mantle viscosity and lithospheric thickness under Iceland
}

\author{
Auke Barnhoorn, Wouter van Der Wal, Martyn R. Drury
}

\section{To cite this version:}

Auke Barnhoorn, Wouter van Der Wal, Martyn R. Drury. Upper mantle viscosity and lithospheric thickness under Iceland. Journal of Geodynamics, 2011, 52 (3-4), pp.260. 10.1016/j.jog.2011.01.002 . hal-00780030

\section{HAL Id: hal-00780030 https://hal.science/hal-00780030}

Submitted on 23 Jan 2013

HAL is a multi-disciplinary open access archive for the deposit and dissemination of scientific research documents, whether they are published or not. The documents may come from teaching and research institutions in France or abroad, or from public or private research centers.
L'archive ouverte pluridisciplinaire HAL, est destinée au dépôt et à la diffusion de documents scientifiques de niveau recherche, publiés ou non, émanant des établissements d'enseignement et de recherche français ou étrangers, des laboratoires publics ou privés. 


\section{Accepted Manuscript}

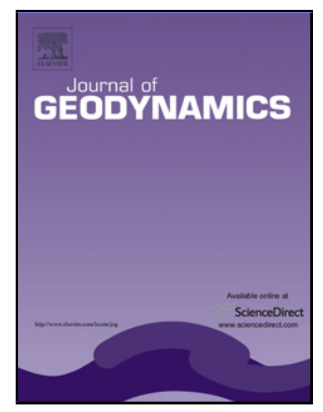

Title: Upper mantle viscosity and lithospheric thickness under Iceland

Authors: Auke Barnhoorn, Wouter van der Wal, Martyn R.

Drury

PII: $\quad$ S0264-3707(11)00028-7

DOI: $\quad$ doi:10.1016/j.jog.2011.01.002

Reference: $\quad$ GEOD 1044

To appear in: $\quad$ Journal of Geodynamics

Received date: $\quad 27-7-2010$

Revised date: 27-1-2011

Accepted date: $\quad 30-1-2011$

Please cite this article as: Barnhoorn, A., van der Wal, W., Drury, M.R., Upper mantle viscosity and lithospheric thickness under Iceland, Journal of Geodynamics (2010), doi:10.1016/j.jog.2011.01.002

This is a PDF file of an unedited manuscript that has been accepted for publication. As a service to our customers we are providing this early version of the manuscript. The manuscript will undergo copyediting, typesetting, and review of the resulting proof before it is published in its final form. Please note that during the production process errors may be discovered which could affect the content, and all legal disclaimers that apply to the journal pertain. 
- Rheological modeling of upper mantle under Iceland

- Low upper mantle viscosity and lithospheric thickness

- Modeling shows large lateral variations in viscosity and lithospheric thickness

- Indications for a dry upper mantle under Iceland

- Increase in lithospheric thickness away from the mid-oceanic ridge axis 


\author{
Auke Barnhoorn $^{1 *}$, Wouter van der Wal ${ }^{2,1}$, Martyn R. Drury ${ }^{1}$
}

$5{ }^{1}$ Department of Earth Sciences, Faculty of Geosciences, University of Utrecht, The

6 Netherlands

$7 \quad{ }^{2}$ Faculty of Aerospace Engineering, Delft University of Technology, The Netherlands

Abstract

Deglaciation during the Holocene on Iceland caused uplift due to glacial isostatic adjustment.

11 Relatively low estimates for the upper mantle viscosity and lithospheric thickness result in rapid uplift responses to the deglaciation cycles on Iceland. The relatively high temperatures of the upper mantle under the newly formed mid-ocean ridge under Iceland are responsible for the low upper mantle viscosity values. In this study, estimates for lithospheric thickness and upper mantle viscosity under Iceland from glacial isostatic adjustment studies are complemented by a microphysical modelling approach using the theoretical temperature distribution under mid-ocean ridges combined with olivine diffusion and dislocation creep flow laws. The lithospheric thickness $(27-40 \mathrm{~km})$ and upper mantle viscosity $\left(2 \times 10^{18}-10^{19}\right.$ Pas) outcomes for the upper mantle recent glaciation under the Vatnajökull glacier are consistent with previous reports of viscosity and lithospheric thickness from glacial isostatic adjustment studies. A combination of a $40 \mathrm{~km}$ thick elastic lithosphere and an average upper mantle viscosity of $5 \times 10^{18}$ Pas would suggest that the upper mantle under Iceland is most

23 likely dry. The earlier and larger Weichselian glaciation event ( 10000 BP) on Iceland is

24 predicted to have had a slightly larger upper mantle viscosity $\sim 10^{19}$ Pas and a lithospheric

\footnotetext{
* Corresponding author. Phone: +31 30 2531199, Fax: +31 253 7725, E-mail: auke.barnhoorn@geo.uu.nl
} 
thickness of $\sim 100 \mathrm{~km}$. Large lateral variations in upper mantle viscosity and especially lithospheric thickness are expected for Iceland perpendicular to the ridge axis.

\section{Keywords}

Rheology, deformation mechanism, creep, water content, melt content, mid-ocean ridge, plume

\section{Introduction}

The Vatnajökull glacier, located in the south-east of Iceland is the largest ice cap of Iceland having a mean radius of $50.7 \mathrm{~km}$ covering an area of $\sim 8100 \mathrm{~km}^{2}$ (Björnsson, 1998). Its estimated mass loss since 1890 is $435 \mathrm{~km}^{3}$ (Árnadóttir et al., 2009), much more than the earlier estimate by Sigmundsson and Einarsson (1992) where the mass loss between 1890 and 1978 is estimated at only $182 \mathrm{~km}^{3}$. The Vatnajökull glacier is situated directly on top of the spreading axis in the eastern volcanic zone (EVZ) of the Icelandic mid-ocean ridge and near the inferred centre of the Icelandic hotspot (e.g. Wolfe et al., 1997). Due to the vicinity of the glacier to the active tectonic area, the response of the solid earth to melting of the ice cap is strongly controlled by the properties of the newly formed upper mantle underneath the midocean ridge. The relatively high temperatures in the mantle during rifting result in relatively low upper mantle viscosities and fast relaxation times in comparison with tectonically stable areas such as Fennoscandia. Upper mantle viscosity estimates from glacial isostatic adjustment (GIA) studies for Iceland range between $5 \times 10^{17}$ Pas and $5 \times 10^{19}$ Pas (e.g. Sigmundsson, 1991; Sigmundsson and Einarsson, 1992; Thoma and Wolf, 2001; Sjöberg et al., 2004; Fleming et al., 2007; Pagli et al., 2007; Biessy et al., 2008; Árnadóttir et al., 2009; Le Breton et al., 2010) compared to $10^{20}-10^{21}$ Pas in Fennoscandia (e.g. Lambeck et al., 1998; Milne et al., 2001). Elastic thickness estimates in those studies including estimates from 
seismological studies (e.g. Kaban et al., 2002; Kumar et al., 2005) range between a very thin lithospheric thickness of $10 \mathrm{~km}$ up to $80 \mathrm{~km}$. Recent glacial isostatic adjustment studies by Pagli et al. (2007) and Árnadóttir et al. (2009) provides estimates for both the lithospheric thickness and the upper mantle viscosity. It resulted in a lithospheric thickness of 10-20 km and a viscosity of 4-10x10 18 Pas for Pagli et al. (2007) and a lithospheric thickness of $40 \mathrm{~km}$ and a viscosity of $10^{19}$ Pas for Árnadóttir et al. (2009).

In this study, we present a microphysical approach to determine the lithospheric thickness (elastic layer) and upper mantle viscosity under the Icelandic mid-ocean ridge and specifically under the Vatnajökull glacier. Information on the rheological behaviour of the main upper mantle mineral olivine is combined with information on the temperature distribution under mid-ocean ridges, information on the microstructural state of the upper mantle under mid-ocean ridges (grain size, water content) and stress levels within the upper mantle due to glaciation events to determine the viscosity of the upper mantle. This approach provides detailed estimates on the lateral and radial variations in upper mantle viscosity and lithospheric thickness that can be tested in geodynamical models and compared with glacial isostatic adjustment studies that so far neglected lateral variability in viscosity and lithospheric thickness. In this study, we have based estimates of viscosity and elastic thickness for Iceland on data from the temperature distribution of the mantle under oceanic lithosphere calculated from a half-space cooling model for oceanic lithosphere (Turcotte and Schubert, 2002) and the olivine flow laws from Hirth and Kohlstedt (2003) for linear diffusion creep and non-linear dislocation creep in a wet and dry upper mantle. The half-space cooling model simulates a normal mid-ocean ridge setting and a simplified approximation of plume activity under Iceland. Temperatures of the plume at the center of the ridge axis are $100{ }^{\circ} \mathrm{C}$ and $200{ }^{\circ} \mathrm{C}$ higher than temperatures at the ridge in a mid-ocean ridge setting, based on estimates of excess temperatures of $75-200{ }^{\circ} \mathrm{C}$ due to plume activity under Iceland (e.g. Ito 
et al., 1996; 1999; Ruedas et al., 2004; Schmeling and Marquart, 2008). The static temperature distribution in the upper mantle, based on the half-space cooling model, used here (Fig. 1) is less complicated than dynamic models for plume activity and mantle melt generation (e.g. Ito et al., 1996; 1999; Ruedas et al., 2004; Marquart, 2001; Schmeling and Marquart, 2008). However, those models only contain a relatively simple dependency of viscosity on pressure and temperature, whereas the viscosity dependence of this study includes also the influence of water, melt fraction and grain size. By using the flow laws of Hirth and Kohlstedt (2003) for olivine rheology, solid-state viscosity variations (both radially and laterally) under an active mid-ocean ridge are calculated. The study shows that large variations in elastic thickness and viscosity are expected under the mid-ocean ridge setting of Iceland due to cooling-related temperature variations.

\section{Temperature dataset and olivine viscosity modeling}

Geotherms for the oceanic lithosphere under Iceland are constructed using a time-dependent half-space cooling model (Turcotte and Schubert, 2002):

$$
T(z)=T_{s}+\left(T_{m}-T_{s}\right) \operatorname{erf}\left(z / 2 \sqrt{\kappa \tau_{c}}\right)
$$

where $T_{\mathrm{s}}$ is the surface temperature, $\mathrm{T}_{\mathrm{m}}$ the mantle temperature at a depth of $410 \mathrm{~km}$ (in this study we used $\mathrm{T}_{\mathrm{m}}=1400,1500$ or $\left.1600{ }^{\circ} \mathrm{C}\right), \tau_{\mathrm{c}}$ the age of the oceanic lithosphere and $\kappa$ the thermal diffusivity (taken as $1 \mathrm{~mm}^{2} \mathrm{~s}^{-1}$; Turcotte and Schubert, 2002). Estimates of upper mantle temperatures from Goes et al. (2000) using P- and S-wave tomography data for Iceland (Fig. 1A) give temperatures in accordance with a time-dependent cooling model of the oceanic lithosphere. The oldest volcanic rocks outcropping on Iceland have an age of approximately $16 \mathrm{Ma}$ (Foulger, 2006). The steady-state spreading rate of Iceland in plate motion models is 19-20 mm/year (e.g. Árnadóttir et al., 2009). Average growth rate of each plate on both sides of the spreading ridge is thus around $1 \mathrm{~cm} / \mathrm{year}=10 \mathrm{~km} / \mathrm{Ma}$. Based on the 
100

101

102

103

104

where $A$ and $\alpha$ are constants, $n, p$ and $r$ are the stress, grain size and water fugacity exponents,

age constraint and the spreading rate, geotherms for the oceanic lithosphere between 0 and 20 Ma (Fig. 1A) and a two-dimensional cross-section of the temperature distribution under the Icelandic mid-ocean ridge (Fig. 1B) are constructed. The cross-section encompasses the first $200 \mathrm{~km}$ on either side of the ridge axis corresponding to the first $20 \mathrm{Ma}$ of oceanic lithosphere generation. Mantle temperatures at the base of the modelled range are set at 1400, 1500 and $1600{ }^{\circ} \mathrm{C}$ to reflect the temperature distribution in a normal mid-ocean ridge setting $\left(\mathrm{T}_{\mathrm{m}}=1400\right.$ ${ }^{\circ} \mathrm{C}$; Turcotte and Schubert, 2002) and settings where a plume with excess temperatures for Iceland of 100-200 C (e.g. Ito et al., 1996; 1999; Maclennan et al., 2001; Ruedas et al., 2004; Putirka, 2005; Schmeling and Marquart, 2008) is imposed on a mid-ocean ridge setting $\left(\mathrm{T}_{\mathrm{m}}=\right.$ 1500 and $1600{ }^{\circ} \mathrm{C}$ ). The olivine-wadsleyite transition at $\sim 410 \mathrm{~km}$ is taken as the lower boundary of the vertical temperature distribution in the upper mantle (Fig. 1B). The dry solidus of for an anhydrous mantle and the solidus at $100 \mathrm{ppm} \mathrm{H}_{2} \mathrm{O}$ for a wet upper mantle of Hirschmann et al. (2009) are taken as melting curves. When the temperatures along the geotherms of Fig. 1A exceed the solidus temperature a partially molten upper mantle is assumed to be present (Fig. 1C).

\section{Olivine viscosity modelling}

Diffusion and dislocation flow laws for olivine from Hirth and Kohlstedt (2003) are used to calculate the upper mantle viscosity distribution for a dry/wet and melt-free upper mantle and a dry/wet and melt-bearing upper mantle. The diffusion and dislocation creep flow laws describe the dependence of the strain rate $(\dot{\varepsilon})$ on temperature $(T)$, grain size $(d)$, deviatoric stress $(\sigma)$, pressure $(P)$, water content $\left(\mathrm{fH}_{2} \mathrm{O}\right)$ and melt content $(\varphi)$ :

$$
\dot{\varepsilon}=A \sigma^{n} d^{-p} f H_{2} O^{r} \exp (\alpha \phi) \exp (-E+P V / R T)
$$

$124 E$ the activation energy and $V$ the activation volume. For the modeling of dry/wet, melt- 
bearing upper mantle a melt fraction $(\phi)$ of $\phi=0.04$ is used. A melt content of $4 \%$ is just

126

127 above the upper limit for estimates for melt that can remain in a peridotite (up to 2-3\%; Faul (1997), 1-3\%; Ruedas et al. (2004)). We have used a higher value of $4 \%$ to illustrate that the presence of melt has only a relatively small reducing effect on the overall viscosity within the upper mantle under Iceland. A study of the Oman ophiolite (Dijkstra et al., 2002) shows that olivine grain sizes in mantle rocks of mid-ocean ridges have grain sizes between 0.8 and 3.3 $\mathrm{mm}$. An average grain size of $2 \mathrm{~mm}$ is used in the modelling as a representative grain size for the upper mantle in mid-ocean ridge settings. Stress profiles within the upper mantle due to glacial loading have been calculated for Iceland using a three-dimensional finite element model for glacial isostatic adjustment based on the commercial program Abaqus. We use the geometry of Schotman et al. (2009) who studied Scandinavia, and scaled down the spatial dimensions by a factor of 10 because the Icelandic glaciations cover a much smaller area. The model has a total of $97 \times 97$ elements in the horizontal direction and 7 element layers in the vertical direction. Elements in the inner surface area of 292 x $292 \mathrm{~km}$ are 8 x $8 \mathrm{~km}$ wide.

Density and Young's modulus parameters are obtained by volume averaging from PREM. The rheology is a combination of dislocation and diffusion creep (Van der Wal et al., 2010) with parameters taken from Hirth and Kohlstedt (2003) and a temperature-depth profile for a cooling oceanic lithosphere of 4 million years old (Turcotte and Schubert, 2002). The top 15 kilometer is taken to be fully elastic, which is reasonably close to the $10 \mathrm{~km}$ elastic thickness of Sigmundsson (1991). Note however, that the real elastic thickness in the model for glacial loading depends on the effective viscosity which is a function of stress.

The model is loaded separately by two glaciations. (i) the Weichselian (or Younger Dryas) glaciation is modelled following Sigmundsson (1991), approximating the ice cap by four discontinuities in height. The surface extent of the ice cap is $160 \mathrm{~km}$ and the maximum height is $1800 \mathrm{~m}$. We have included a 100000 year growth phase of the ice cap ; unloading 
takes place at different time steps between 10000 and 9500 years before present according to Sigmundsson (1991). (ii) A model for the recent growing and melting of the Vatnajökull ice cap is taken from Fleming et al. (2007). A perfectly plastic ice cap (discretised on our 8 x 8 $\mathrm{km}$ elements) grows from a radius of $45 \mathrm{~km}$ and central thickness of $800 \mathrm{~m}$ at $900 \mathrm{AD}$ to a radius of $52 \mathrm{~km}$ and a central thickness of $915 \mathrm{~m}$ at $1890 \mathrm{AD}$. After that melting takes place in two different rates to end up with a radius of $51 \mathrm{~km}$ and $904 \mathrm{~m}$ in $2001 \mathrm{AD}$. The GIA model provides the von Mises equivalent stress as output:

$$
q=\sqrt{\frac{3}{2} \sigma_{i j} \sigma_{i j}}
$$

where $\sigma_{i j}$ is an element of the stress tensor. Von Mises equivalent stresses are calculated at the center of the layers $(3.75,11.25,20,37.5,70,120,185)$ and averaged (Fig. 2) over a horizontal area of $200 \mathrm{~km}$ radius and also averaged over time (from $20 \mathrm{ka} \mathrm{BP}$ up to $9 \mathrm{ka} \mathrm{B.P.}$ for the Weichselian ice cap; from 10 ka B.P. up to 2001 for the recent melting of the Vatnajökull ice cap). The stresses are interpolated for every kilometre in the upper mantle to produce Fig. 2. Using a faster melt rate between 1890 and 2003 (Árnadóttir et al. , 2009) than reported by Fleming et al. (2007) resulted in average stress values that differed by less than $7 \%$ in areas where the stress is high enough to influence the effective viscosity. The resulting difference in stress using both melt rate estimates is too small to significantly influence the outcomes of this microphy modelling study. The Von Mises stress is a measure of deviatoric stress and can be used directly in flow laws derived from uni-axial experiments (Ranalli, 1995). We assume that the equivalent stress can be used as the stress parameter in Eq. (2). The von Mises stresses is the equivalent stress multiplied by $\sqrt{ } 3$. The maximum equivalent stress value of $1 \mathrm{MPa}$ at shallow depths for the Weichselian glaciation (Fig. 2) can be compared to estimates of an average stress in the lithosphere and upper mantle due to a simple model of glacial unloading in Scandinavia which are in the range of $\sim 0.5$ to at maximum 30 
$174 \mathrm{MPa}$ (Barnhoorn et al., in press). The smaller ice cap of Iceland in comparison to Scandinavia

175 causes the average stresses due to glacial loading to be lower for this study. A stress of $1 \mathrm{MPa}$

176 is also the lower stress estimate for convective processes in the upper mantle (Ranalli, 1995).

177 Pressure $(P)$ is calculated as $P=0.033 G P a / \mathrm{km}$.

178 A composite flow law (e.g. Ranalli, 1995) in which both competing mechanisms

179 dislocation creep and diffusion creep contribute to the deformation is used to calculate the

180 total viscosity where:

181

$$
\dot{\varepsilon}_{\text {total }}=\dot{\varepsilon}_{\text {diff }}+\dot{\varepsilon}_{\text {disl }}
$$

182

and

$$
\eta_{\text {disl }}=\sigma / 2 \dot{\varepsilon}_{\text {disl }} ; \quad \eta_{\text {diff }}=\sigma / 2 \dot{\varepsilon}_{\text {diff }} ; \quad \eta_{\text {total }}=\sigma / 2 \dot{\varepsilon}_{\text {total }}
$$

Two melt contents have been modelled $(0 \%$ and $4 \%)$ for a dry $\left(\mathrm{C}_{\mathrm{OH}}=0 \mathrm{H} / 10^{6} \mathrm{Si}\right)$ and wet upper mantle $\left(\mathrm{C}_{\mathrm{OH}}=100 \mathrm{H} / 10^{6} \mathrm{Si}\right)$. The lateral extent of the melting zone in the $4 \%$ melt scenario is controlled by the crossing of the geotherm with the solidus of the upper mantle of Hirschmann et al (2009). Melt-controlled rheology is in this scenario concentrated under the present-day ridge axis and extends $\sim 120 \mathrm{~km}$ for $\mathrm{T}_{\mathrm{m}}=1400{ }^{\circ} \mathrm{C}$ away from the ridge axis.

Outside of this melting zone, the upper mantle deforms by a melt-free rheology $(\varphi=0)$. The lithospheric thickness is defined as the layer in which the viscosity is high enough so that no measurable influence on the relaxation process is exerted. Analyses of the viscosity cut-off value for Scandinavia (Barnhoorn et al., in press) shows that viscous deformation starts to affect predicted sea-level changes by around one meter for an average viscosity in the lithosphere below $10^{25}$ Pas. Since relaxation times for the Icelandic ice caps are much smaller than the relaxation times for Scandinavia (hundreds of years compared to tens of thousands of years), we have selected a viscosity cut-off value of $10^{23}$ Pas to represent the maximum viscosity value at which viscous deformation contributes to glacial isostatic adjustment due to recent melting on Iceland. We have determined the lithospheric thickness for any distance 
away from the ridge axis in two ways: 1) as the depth at which the average viscosity from the

200 top surface of the Earth to that depth is less than $10^{23}$ Pas, 2) as the depth at which the

201 viscosity falls below $10^{20}$ Pas. We have chosen a maximum viscosity value of $10^{20}$ Pas since

202 Árnadóttir et al. (2009) state that in their GIA model the lithosphere behaves essentially

203 elastic above $10^{20}$ Pas. The lithospheric thickness varies in both cases perpendicular to the

204 ridge axis. Below the lithosphere, the upper mantle is deforming viscously and the average

205 viscosity values reported here are the averages of the viscosity values below that lithospheric

206 thickness. The radius of $\sim 50 \mathrm{~km}$ for the Vatnajökull glacier present nowadays (Sigmundsson,

207 1991) indicates that roughly the first vertical $100 \mathrm{~km}$ of the upper mantle is affected by recent

208 glaciation, whereas the radius of $\sim 160 \mathrm{~km}$ present during the Weichselian glaciation

209 (Sigmundsson, 1991) indicates that in that period the first $\sim 300 \mathrm{~km}$ of the upper mantle is

210 affected by the Weichselian glaciations. In addition, our stress distribution profiles calculated

211 for both glaciation events show that at depths of $100 \mathrm{~km}$ for the recent glaciation event and at

$212300 \mathrm{~km}$ for the Weichselian glaciation event the upper mantle is still subjected to some

213 loading induced stresses. At larger depths for both events the stresses decrease towards zero.

214 We therefore have calculated average viscosities from depths below the lithospheric thickness

215 to a depth of $100 \mathrm{~km}$ for recent glacial isostatic adjustments on Iceland and from depths below

216 the lithospheric thickness to a depth of $300 \mathrm{~km}$ for the glacial isostatic adjustment during the

217 Weichselian period. Maximum depths of the upper mantle affected by the glaciation events

218 are approximations. Establishing the exact depth-sensitivity requires more detailed

219 computations using for example Frechet kernels (Mitrovica and Peltier 1991). Horizontally

220 averaged viscosity profiles and vertically averaged viscosity trends have been produced for

221 both glaciation events. Single values representing the average viscosities and lithospheric

222 thicknesses under both icecaps have been determined for comparison with glacial isostatic 
adjustment studies on Iceland. Those studies usually assume that the upper mantle under

224 Iceland only has one viscosity and lithospheric thickness without any lateral variations.

\section{Results}

227 The rheological modelling for the Iceland mid-ocean ridge shows that diffusion creep

228 dominates the deformation in the upper mantle (Fig. 3). Only at shallow depths under the

229 mid- ocean ridge a small region can occur where dislocation creep dominates the deformation.

230 This is only the case for the Weichselian glaciation event. All deformation during the recent

231 glaciation event is controlled by diffusion creep according to our model. As a result of the

232 dominance of diffusion creep under Iceland most of the upper mantle experiences stress-

233 independent viscosities and therefore the Weichselian and recent glaciation events produced

234 almost identical viscosity fields within the upper mantle (Fig. 4). Significant variations in

235 upper mantle viscosity occur during both glaciation events both with depth and with

236 increasing distance from the ridge axis (Fig. 4). The radial variations in viscosity are

237 characterised by a decrease in viscosity up to depths of $\sim 70 \mathrm{~km}$ caused by the rapid increase

238 in temperature with depth and the presence of a partially molten region to depths of $\sim 70 \mathrm{~km}$

239 (Fig.2b). Below that the radially averaged viscosity (Fig. 5) increases from depths $>70 \mathrm{~km}$ to

$240410 \mathrm{~km}$ caused by the increased importance of the pressure dependence of the rheology (Fig.

2414 and 5), while temperatures are relatively constant at those depths (Fig. 1).

242 The microphysical modelling shows a strong, but narrow low-viscosity layer for the

243 Weichselian glaciation at depths of $\sim 30-70 \mathrm{~km}$ (Fig. 6) due to the influence of the melt

244 content on viscosity and the increase in temperature close to reaching the adiabatic

245 temperature gradient. The decrease in viscosity in this layer due to the presence of the melt is

$246 \sim 1-2$ orders of magnitude in comparison with the viscosities in a melt-free upper mantle. The

247 low viscosity zone for the recent glaciation starts even shallower $(\sim 15 \mathrm{~km})$ due to closer 
proximity of the Vatnajökull glacier to the mid-ocean ridge axis where higher temperatures prevail (Fig. 6). A wet upper mantle $\left(\mathrm{C}_{\mathrm{OH}}=100 \mathrm{H} / 10^{6} \mathrm{Si}\right)$ results in a reduction of the viscosity of around 1 order of magnitude in comparison with a dry upper mantle (Fig. 5B and 5D). The melting temperatures for a wet upper mantle solidus are lower than those for a dry upper mantle (Fig. 1) causing the partially-molten region, and hence melt-induced lowering of the viscosity, to extend to larger distances away from the mid-ocean ridge axis within a wet upper mantle (Fig. 1 and Fig. 5). Plume activity within the upper mantle under Iceland may have resulted in lower upper mantle viscosities than in a normal mid-ocean ridge scenario. Higher temperatures in the range of $\Delta T$ of $100-200{ }^{\circ} \mathrm{C}$ have been postulated for Iceland (e.g. Ito et al., 1996; 1999; Maclennan et al., 2001; Ruedas et al., 2004; Putirka, 2005; Schmeling and Marquart, 2008). We have simulated the effect of additional plume activity on Iceland by increasing the mantle temperatures at the bottom of time-dependent half-space cooling model (Turcotte and Schubert, 2002) with 100 and $200{ }^{\circ} \mathrm{C}$ to $\mathrm{T}_{\mathrm{m}}=1500{ }^{\circ} \mathrm{C}$ or $1600{ }^{\circ} \mathrm{C}$ (Fig. 7). The higher temperatures with the mantle due to the plume lower the viscosities by $\sim 0.6$ orders of magnitude per $100{ }^{\circ} \mathrm{C}$ excess temperatures (Fig. 6 and 8).

The vertical temperature gradients and resulting viscosity gradients underneath a midocean ridge result in a large increase in lithospheric thickness (Fig. 5A and 5C) with an increasing distance from the ridge axis irrespective of the method used to determine the lithospheric thickness (the depth at which the average viscosity between the top and bottom of

267 the elastic layer falls below $10^{23}$ Pas or the depth at which the viscosity is smaller than $10^{20}$ 268 Pas). The temperature gradients due to cooling of the lithosphere away from the ridge axis cause a rapid increase in viscosity in cooled upper mantle material thereby increasing the

270 lithospheric thickness. Melt content in the partially molten region only slightly lowers the 271 lithospheric thickness (at maximum a couple of kilometres, Fig. 5A and 5C). The stress- 
independent viscosities for Iceland due to the dominance of diffusion creep results in similar lithospheric thicknesses for the Weichselian and recent glaciation events (Fig. 5A and 5C),

Fig. 5 shows that defining the lithosphere as the depth at which the average viscosity is lower than $10^{23}$ Pas produces thicknesses significantly larger than defining the lithosphere as the depth at which the viscosity is lower than $10^{20}$ Pas $(\sim 130-150 \mathrm{~km}$ at a distance of $200 \mathrm{~km}$ (20 Ma upper mantle from the mid-ocean ridge axis, Fig. 5) versus $\sim 50 \mathrm{~km}$ ). Close to the ridge axis the viscosity gradient is so high that both methods result in more similar lithospheric thicknesses (differences smaller than $50 \mathrm{~km}$ ). Excess temperatures due to plume activity lower the viscosity estimates for the upper mantle under Iceland and thus also lower the lithospheric thickness. Lithospheric thicknesses $200 \mathrm{~km}$ away from the mid-ocean ridge axis are reduced by $\sim 20 \mathrm{~km}$ per $100{ }^{\circ} \mathrm{C}$ excess temperatures using the lithospheric thickness definition of average viscosity below $10^{23}$ Pas and only a reduction of a few kilometres per $100{ }^{\circ} \mathrm{C}$ excess temperatures (Fig. 8) using the lithospheric thickness definition of a viscosity below $10^{20}$ Pas.

Vertically averaged upper mantle viscosity estimates below the elastic lithosphere in sections from the ridge axis to a distance of $200 \mathrm{~km}$ from the ridge axis are fairly constant (Fig. 5B and 5D) for both the Weichselian and recent glaciation events with the lowest average viscosities at the ridge axis. However, averaged viscosities for the recent glaciation event are considerably lower than the averaged viscosities for the Weichselian glaciation event (Fig. 5B and 5D). This is primarily caused by the fact that the upper mantle viscosities for the Weichselian glaciation are averaged from the bottom of the elastic layer to a depth of $300 \mathrm{~km}$ (maximum depth affected by the Weichselian glaciation), whereas for the recent glaciation event the viscosities are averaged between the bottom of the elastic layer to a depth of $100 \mathrm{~km}$. Thus, Weichselian viscosity averages are dominated by the larger viscosity values of the deeper parts of the upper mantle with only a relatively minor influence of the shallow 
low-viscosity zone, whereas recent viscosity averages are primarily dominated by the viscosities of the shallow low-viscosity zone (Fig. 6). For a dry upper mantle, average upper mantle viscosities are predicted to be between $\sim 6 \times 10^{18}$ Pas and $1 \times 10^{19}$ Pas for the Weichselian glaciation event and $\sim 1 \times 10^{18}$ Pas and $8 \times 10^{18}$ Pas for the recent glaciation event (Fig. 5). In the case of a wet upper mantle, average upper mantle viscosities range are predicted to be between $3 \times 10^{18}$ Pas and $7 \times 10^{18}$ Pas during the Weichselian glaciation event and $7 \times 10^{17}$ Pas and $7 \times 10^{18}$ Pas for the recent glaciation event (Fig. 5).

To compare the results of this microphysical modelling with estimates of constant viscosity and constant lithospheric thickness from glacial isostatic adjustment studies for Iceland we have produced a single upper mantle viscosity value and lithospheric thickness value for each of the two glaciation events (averaging out all lateral variations in viscosity and thickness). We have used the range in lateral extent for the Weichselian glaciation event underneath all of the land mass of Iceland (Sigmundsson, 1991) and the lateral extent of the Vatnajökull glacier for the recent glaciation event to determine the average viscosities and lithospheric thicknesses. Maximum viscosity values in a dry upper mantle under the recent Vatnajökull glacier are around $5 \times 10^{18}$ Pas and would have been around $10^{19}$ Pas during the Weichselian glaciation. Plume activity and/or a wet upper mantle scenario reduce average viscosities to be around $10^{18}$ Pas or lower (Fig. 9). The average lithospheric thicknesses for both glaciations differ depending on which method is used to define the lithospheric thickness. For the Weichselian glaciation, the average lithospheric thickness in a dry upper mantle are either $100 \mathrm{~km}$ or $\sim 30 \mathrm{~km}$ depending on the definition used and $\sim 40 \mathrm{~km}$ or $\sim 10 \mathrm{~km}$ for the recent glaciation event (Fig. 9). Additional plume activity or a wet upper mantle scenario reduce the lithospheric thickness estimates considerably.

\section{Discussion}


The microphysical modelling in this study predicts the lithospheric thickness and upper mantle viscosities under Iceland using a theoretical temperature distribution under mid-ocean ridges combined with the rheological behaviour of olivine. It results in estimates that are in line with estimates from glacial isostatic adjustment studies and seismological studies. All studies show smaller elastic thicknesses $(<100 \mathrm{~km})$ and relatively low viscosity values $\left(<10^{20}\right.$ Pas) in comparison with studies of continental areas such as Fennoscandia. This is due to the relatively high temperature conditions under the newly formed oceanic lithosphere of Iceland. There is a significant spread in upper mantle viscosity estimates for Iceland between $10^{17}$ Pas and $10^{20}$ Pas and in elastic lithospheric thickness estimates between 10 and $80 \mathrm{~km}$ amongst the different studies (Fig. 10) over the past two decades (Sigmundsson, 1991; Sigmundsson and Einarsson, 1992; Thoma and Wolf, 2001; Kaban et al., 2002; Sjöberg et al., 2004; Kumar et al., 2005; Pagli et al, 2007; Biessy et al., 2008; Árnadóttir et al., 2009; Le Breton et al., 2010). The most recent glacial isostatic adjustment studies that provide estimates of both upper mantle viscosity and lithospheric thickness for Iceland (Pagli et al., 2007; Árnadóttir et al., 2009) are compared with estimates from our study. The best correspondence for the recent glaciation event of both the elastic thickness and average upper mantle viscosity estimates of this study is with the study of Árnadóttir et al. (2009). An average viscosity in the range of $6 \times 10^{18}$ Pas to $\sim 2 \times 10^{19}$ Pas and an elastic thickness of $40 \mathrm{~km}$ (Árnadóttir et al., 2009) is only approached by the results of this study for a dry upper mantle scenario without any additional plume activity (average viscosity $\sim 5 \times 10^{18}$ Pas, Fig. 9). All other scenarios produce too low average viscosity values for the recent glaciation event (Fig. 9). Using the depth at which the viscosity falls below $10^{20}$ Pas as the definition for the lithospheric thickness produces a thickness of $\sim 10 \mathrm{~km}$ (Fig. 9), which is considerably below the thickness preferred by Árnadóttir et al. (2009). This suggests that using the definition of the depth at which the average viscosity is lower than $10^{23}$ Pas results in more realistic estimates of lithospheric 
thicknesses in this microphysical study. Using the preferred dry upper mantle scenario with a

348 lithospheric thickness definition of an average viscosity smaller than $10^{23}$ Pas results in an

349 average viscosity of $10^{19}$ Pas and an lithospheric thickness of $\sim 100 \mathrm{~km}$ for the Weichselian

350 glaciation event (Fig. 9). Our viscosity estimates are in line with estimates of glacial isostatic

351 adjustment studies for the Weichselian deglaciation (Sigmundsson 1991, Biessy et al 2008;

352 Le Breton et al. 2010), although here significantly larger lithospheric thickness values ( 100

$353 \mathrm{~km}$ ) are predicted for the Weichselian glaciation event than the $\sim 15 \mathrm{~km}$ lithospheric thickness

354 predicted by Sigmundsson (1991). A correspondence of the upper mantle viscosities estimates

355 of this study can also be achieved with the study for the recent glaciation event of Pagli et al.

356 (2007). A mean upper mantle viscosity of $\sim 10^{18}$ Pas of Pagli et al. (2007) would imply that

357 the upper mantle under Iceland is most likely wet (Fig. 9), as a dry upper mantle produces a

358 higher average viscosity of $\sim 5 \times 10^{18}$ Pas. However, the lithospheric thickness estimates of 10-

$35920 \mathrm{~km}$ of Pagli et al. (2007) do not correspond to our estimates of elastic thickness in a wet

360 upper mantle of $\sim 30 \mathrm{~km}$. Upper mantle viscosity values in the range of $10^{18}$ Pas can also be

361 achieved by the presence of a plume under Iceland affecting the viscosities of the mantle. This

362 possibility can not be excluded in the comparison with Pagli et al. (2007), but a plume can not

363 explain the viscosity estimates of Árnadóttir et al. (2009). Upper mantle viscosity estimates in

364 the range of $10^{17}$ Pas (e.g. Sjöberg et al., 2004) or as high as $10^{20}$ Pas are not preferred by

365 Árnadóttir et al (2009) since they do not fit with recent GPS uplift data for Iceland. Using our

366 modeling approach, very low viscosities values around $10^{17}$ Pas can only be produced with

367 either a very wet upper mantle $\left(\mathrm{C}_{\mathrm{OH}} \geq 1000 \mathrm{H} / 10^{6} \mathrm{Si}\right)$ or with very high deep mantle

368 temperatures due to additional plume activity under Iceland $\left(\mathrm{T}_{\mathrm{m}}>1600{ }^{\circ} \mathrm{C}\right)$. Upper mantle

369 viscosity estimates around $10^{20}$ Pas or even higher can on the other hand only be achieved by

370 having very large olivine grain sizes around 5-10 $\mathrm{mm}$ in a dry upper mantle, which is much

371 larger than the average grain size present at mid-ocean ridges (e.g. Dijkstra et al., 2002). Since 
those very low or very high viscosity estimates do not fit with the most recent uplift rate

373 scenarios (Árnadóttir et al., 2009), a wet and/or hot upper mantle scenario or a very large

374 grain size in combination with a dry upper mantle scenario are not likely to be present in the 375 upper mantle under Iceland.

376 By comparing the glacial isostatic adjustments studies of Pagli et al. (2007) and

377 Árnadóttir et al. (2009) with this study using a different approach, similar and relatively low

378 average upper mantle viscosity estimates for the mid-ocean ridge under Iceland can be

379 obtained. However, this study shows that lateral variations in upper mantle viscosity and

380 lithospheric thickness are likely to occur under an active tectonic setting such as the Icelandic

381 mid-ocean ridge. A large heterogeneity in temperature distribution within the upper mantle

382 causes large lateral and radial variability in viscosity. So far, glacial isostatic adjustment

383 studies have neglected any lateral variability in their geophysical models of the upper mantle

384 (e.g. Sigmundsson, 1991; Sigmundsson and Einarsson, 1992; Sjöberg et al., 2004; Fleming et

385 al., 2007; Árnadóttir et al. 2009). This study shows that glacial isostatic adjustment studies of

386 Iceland, particularly concerning the Weichselian glaciation event, should in the future

387 incorporate such lateral and radial variability in viscosity and lithospheric thickness.

388 The modelling of a mid-ocean ridge setting assumes a relatively thin crust of $<10 \mathrm{~km}$

389 under Iceland. Different observations of the thickness of the crust under Iceland are reported

390 with thickness varying between a thin crust scenario of $10-15 \mathrm{~km}$ and a thick crust scenario of

$39120-40 \mathrm{~km}$ (summarised by Björnsson, 2008). If, in the thick crust scenario, the temperature

392 distribution of the thickened crust is the same as the temperature distribution would be in a

393 time-dependent cooling lithosphere, then the mechanically defined elastic lithosphere values

394 reported here would still be valid estimates. If, on the other hand, the thickened crust under

395 Iceland is also significantly cooler, then the lithospheric thicknesses of $25-40 \mathrm{~km}$ obtained in 
this study will be too small. The thin crust scenario, also favoured by Björnsson (2008) for

397 Iceland, is in line with the mid-ocean ridge model used in this study. In conclusion, based on the closest match of upper mantle viscosity and lithospheric thickness between Árnadóttir et al. (2009) and this study, upper mantle viscosity estimates around $5 \times 10^{18}$ Pas of this study for the recent glaciation event are preferred, implying that a dry upper mantle is most likely present under Iceland. A dry upper mantle scenario is in contrast with the conclusion drawn from a similar rheological modelling study for Scandinavia and where a wet upper mantle was concluded to be most likely present (Barnhoorn et al., in press; Schotman et al., 2009). The different outcomes may point to lateral variations in water content within the upper mantle e.g. between continental lithosphere and oceanic lithosphere.

\section{Conclusions}

Microphysical modelling using the temperature distribution under mid-ocean ridges combined with olivine diffusion and dislocation creep flow laws with an olivine grain size of $2 \mathrm{~mm}$ and stress distributions for the upper mantle produced lithospheric thickness and upper mantle viscosity estimates for the upper mantle under Iceland during the Weichselian glaciation event and the recent glaciation event which nowadays forms the Vatnajökull glacier. Using the most

414 recent estimates of Árnadóttir et al. (2009) as best estimates for upper mantle viscosity and 415 lithospheric thickness, the results of this study that best match the estimates of Árnadóttir et al. (2009) (viscosity $\sim 5 \times 10^{18}$ Pas and thickness of $\sim 40 \mathrm{~km}$ ) suggest that the upper mantle

417 under Iceland is most likely dry. Also, the presence of a plume under Iceland can not explain 418 the recent viscosity values reported for Iceland. Glaciation during the Weichselian glaciation event should have produced viscosity values $\sim 10^{19}$ Pas and a lithospheric thickness of $\sim 100$ 
estimate is in line with GIA studies (Sigmundsson 1991, Biessy et al 2008; Le Breton et al. 2010). However, this study predicts a significantly larger Weichselian lithospheric thickness due to the lateral variability of the lithospheric thickness in the modelling. Because the deviatoric stress level is mostly below $1 \mathrm{MPa}$, dislocation creep only dominates in a small area underneath the ridge axis. However, viscosity between the two Weichselian and recent glaciations still differs because of the depth-sensitivity which depends on the size of the ice caps. Large lateral variations in upper mantle viscosity and lithospheric thickness are present perpendicular to the ridge axis with a lithospheric thickness in excess of $100 \mathrm{~km}$ at $200 \mathrm{~km}$ from the ridge axes.

\section{Acknowledgements}

432 Financial support from the Netherlands Organisation for Scientific Research (NWO) and TOPO-Europe is acknowledged. Constructive reviews by two reviewers significantly

434 improved the manuscript.

\section{References}

437 Árnadóttir, T., Lund, B., Jian, W., Geirsson, H., Björnsson, H., Einarsson, P., Sigurdsson, T., 438 2009. Glacial rebound and plate spreading: results from the first countrywide GPS 439 observations in Iceland. Geophysical Journal International 177, 691-716.

440 Barnhoorn, A., van der Wal, W., Vermeersen, L.L.A., Drury, M.R. 2010 in press. Lateral 441 radial and temporal variations in upper mantle viscosity and rheology under Scandinavia. 442 Geochemistry Geophysics Geosystems.

443 Biessy, G., Dauteuil, O., Van Vliet-Lanoe, B., Wayolle, A., 2008. Fast and partitioned 444 postglacial rebound of southwestern Iceland. Tectonics 27, TC3002, 445 doi:10.1029/2007TC002177. 
Björnsson, A., 2008. Temperature of the Icelandic crust: Inferred from electrical conductivity, temperature surface gradient, and maximum depth of earthquakes. Tectonophysics 447 , $136-141$.

Björnsson, H., 1988. Hydrology of ice caps in volcanic regions. Reykjavik Societas Scientarium Islandica, University of Iceland. 139 pp.

Dijkstra, A.H., Drury, M.R., Frijhoff, R.M., 2002. Microstructures and lattice fabrics in the Hilti mantle section (Oman Ophiolite): Evidence for shear localization and melt weakening in the crust-mantle transition zone? Journal of Geophysical Research 107, 2270, doi:10.1029/2001JB000458.

Faul, U.H., 1997. Permeability of partially molten upper mantle rocks from experiments and percolation theory. Journal of Geophysical Research 102, 10299-10311.

Fleming, K., Martinec, Z.K., Wolf, D., 2007. Glacial-isostatic adjustment and the viscosity structure underlying the Vatnajökull ice cap, Iceland. Pure and applied geophysics 164, 751-768.

Foulger, G.R., 2006. Older crust underlies Iceland. Geophysical Journal International 165, 672-676.

462 Goes, S., Govers, R., Vacher, P., 2000. Shallow mantle temperatures under Europe from P 463 and S wave tomography. Journal of Geophysical Research 105, 11153-11169. nominally anhydrous mantle: The primacy of partitioning. Physics of the Earth and Planetary Interiors 176 (2009) 54-68

Hirth, G., Kohlstedt, D.L., 2003. Rheology of the upper mantle and the mantle wedge: A view 468 from experimentalists, in Eiler, J. (Ed.), Inside the subduction factory: AGU Geophysical 469 Monograph Series Washington D.C. 138, 83-105. 
Ito, G., Lin, J., Gable, W., 1996. Dynamics of mantle flow and melting at a ridge-centered

471 hotspot: Iceland and the Mid-Atlantic Ridge. Earth and Planetary Science Letters 144, 5374.

Ito, G., Shen, Y., Hirth, G., Wolfe, C.J., 1999. Mantle flow, melting, and dehydration of the 474 Iceland mantle plume. Earth and Planetary Science Letters 165, 81-96.

Kaban, M.K., Flóvenz, O.G., Pálmason, G., 2002. Nature of the crust-mantle transition zone and the thermal state of the upper mantle beneath Iceland from gravity modeling. Geophysical Journal International 149, 281-299.

Kumar, P., Kind, R., Hanka, W., Wylegalla, K., Reigber, C., Yuan, X., Woelbern, I., Schwintzer, P., Fleming, K., Dahl-Jensen, T., Larsen, T.B., Schweitzer, J., Priestley, K., Gudmundsson, O., Wolf, d., 2005. The lithosphere-asthenosphere boundary in the NorthWest Atlantic region. Earth and Planetary Science Letters 236, 249- 257.

Lambeck, K., Smither, C., Johnston, P., 1998. Sea level change, glacial rebound and mantle viscosity for northern Europe. Geophysical Journal International 134, 102- 144.

Le Breton, E., Dauteuil, O., Biessy, G., 2010. Post-glacial rebound of Iceland during the Holocene. Journal of the Geological Society 167, 417-432.

Maclennan, J., McKenzie, D., Gronvöld, K., 2001. Plume-driven upwelling under central Iceland. Earth and Planetary Science Letters 194, 67-82.

Marquart, G., 2001. On the geometry of mantle flow beneath drifting lithospheric plates.

489 Geophysical Journal International 144, 346-372.

490 Milne, G.A., Davis, J.L., Mitrovica, J.X., Scherneck, H.-G., Johansson, J.M., Vermeer, M., 491 Koivula, H., 2001. Space-geodetic constraints on glacial isostatic adjustment in $492 \quad$ Fennoscandia. Science 291, 2381- 2385.

493 Mitrovica, J. X., Peltier, W.R., 1991. A complete formalism for the inversion of post-glacial 494 rebound data: Resolving power analysis. Geophysical Journal International 104, 267-288. 
Pagli, C., Sigmundsson, F., Lund, B., Sturkell, E., Geirsson, H., Einarsson, P., Árnadóttir, T., Hreinsdóttir, S., 2007.Glacio-isostatic deformation around the Vatnajökull ice cap, Iceland, induced by recent climate warming: GPS observations and finite element modeling, Journal of Geophysical Research 112, B08405, doi:10.1029/2006JB004421.

Putirka, K.D., 2005. Mantle potential temperatures at Hawaii, Iceland, and the mid-ocean ridge system, as inferred from olivine phenocrysts: Evidence for thermally driven mantle plumes. Geochemistry Geophysics Geosystems 6, Q05L08, doi:10.1029/2005GC000915.

Ranalli, G., 1995. Rheology of the Earth. Chapman and Hall, London, 436 pp.

Ruedas, T., Schmeling, H., Marquart, G., Kreutzmann, A., Junge, A., 2004. Temperature and melting of a ridge-centred plume with application to Iceland. Part I: Dynamics and crust production. Geophysical Journal International 158, 729-743.

Schmeling, H., Marquart, G., 2008. Crustal accretion and dynamic feedback on mantle melting of a ridge centred plume: The Iceland case. Tectonophysics 447, 31-52.

Schotman, H.H.A., Vermeersen, L.L.A., Wu, P., Drury, M.R., de Bresser, J.H.P., 2009. Constraints on shallow low viscosity zones in Northern Europe from future GOCE gravity data, Geophysical Journal International 178, 65-84.

Sigmundsson, F., 1991. Post-glacial rebound and asthenosphere viscosity in Iceland. Geophysical Research Letters 18, 1131-1134.

Sigmundsson, F., Einarsson, P., 1992. Glacio-isostatic crustal movement caused by historical volume change of the Vatnajökull ice cap, Iceland. Geophysical Research Letters 19, 2123 2126.

Sjöberg, L.E., Pan, M., Erlingsson, S., Asenjo, E., Arnason, K., 2004. Land uplift near Vatnajökull, Iceland, as observed by GPS in 1992, 1996 and 1999. Geophysical Journal International 159, 943-948. 
Thoma, M., Wolf, D., 2001. Inverting land uplift near Vatnajökull, Iceland, in terms of

520 lithosphere thickness and viscosity stratification. In: Sideris, M.G. (Ed.), Gravity, Geoid and

521 Geodynamics 2000 (Springer, Berlin), IAG Symposia 123, 97-102.

522 Turcotte, D.L., Schubert, G., 2002. Geodynamics $2^{\text {nd }}$ edition. Cambridge University Press, $523 \quad 456 \mathrm{pp}$.

524 Van der Wal, W., Wu, P., Wang, H., Sideris, M.G., 2010. Composite rheology in glacial 525 isostatic adjustment modeling, Journal of Geodynamics, 50(1), 38-48, doi:10.1016/j.jog.2010.01.006.

Wolfe, C.J., Bjarnason, I.T., VanDecar, J.C., Solomon, S.C., 1997. Seismic structure of the Iceland mantle plume. Nature 385, 245-247.

Figure captions

Figure 1: A) Geotherms (black lines) for oceanic lithospheres with an age between 0 and 20 Ma (Turcotte and Schubert, 2002) using a mantle temperature of $1400^{\circ} \mathrm{C}$. Dry solidus (red solid line) and wet solidus at 100 ppm $\mathrm{H} 2 \mathrm{O}$ (red dotted line) taken from Hirschmann et al., 2009) and mean temperatures (blue symbols) for Iceland from the temperature dataset of Goes et al. (2000; personal communications) are plotted as well. B) Two-dimensional temperature distribution in the upper mantle under mid-ocean ridges between 0 and $200 \mathrm{~km}$ (equivalent to 0 and 20 Ma using a spreading rate of $1 \mathrm{~cm} /$ year) constructed using the geotherms of Fig. $1 \mathrm{~A}$. Temperature distribution represents a simplified two-dimensional cross-section of the upper mantle under Iceland. The lateral extent of the Vatnajökull glacier during the recent glaciation

540 event and during the Weichselian glaciation event are indicated on the cross-section. C)

541 Partially molten area (red area) in which the temperatures are above the dry solidus (dark red) 542 and wet solidus (light red) temperatures for the mantle. 
544 Figure 2: Averaged von Mises equivalent stress for the upper mantle under Iceland at seven

545 different depths for the Weichselian glaciation (filled squares) and recent glaciation (open

546 squares) determined using a three-dimensional finite element model for glacial isostatic

547 adjustment for Iceland. Stresses between 0 and $410 \mathrm{~km}$ have been interpolated from the von

548 Mises stress determined in the modelling at the seven different depths.

550 Figure 3: Dominant deformation mechanism map for the Weichselian glaciation event in a

551 dry and upper mantle without excess temperatures due to plume activity. Red colours indicate

552 dominance of diffusion creep; blue colour dominance of dislocation creep and brown colours

553 indicate very high viscosities $>10^{30}$ Pas). Lower stress values during the recent glaciation

554 event caused the absence of any dislocation creep dominance underneath the ridge axis.

556 Figure 4: Viscosity distribution under Iceland for a dry and wet $\left(\mathrm{C}_{\mathrm{OH}}=100 \mathrm{H} / 10^{6} \mathrm{Si}\right)$ upper

557 mantle without excess tenperatures due to additional plume activity at melt contents of 0 and, $558 \quad 4 \%$ during the Weichselian glaciation event.

560 Figure 5: Elastic thickness (A and C) and mean upper mantle viscosity (B and D) for Iceland 561 for a dry and wet $\left(\mathrm{C}_{\mathrm{OH}}=100 \mathrm{H} / 10^{6} \mathrm{Si}\right)$ upper mantle at melt contents of 0 and $4 \%$ during the

562 Weichselian (solid lines) and recent glaciation events (broken lines). Elastic thickness at 563 every distance from the ridge axis is determined either as the depth at which the average of

564 the logarithm of the viscosity from the surface to that depth becomes smaller than $10^{23}$ Pas 565 (black lines) or as the depth at which the logarithm of the viscosity becomes smaller than $10^{20}$ 566 Pas (grey lines). Mean upper mantle viscosity at every distance from the ridge axis is the average of the logarithm of the viscosities from the depth of the elastic thickness at that 
distance to a depth of $300 \mathrm{~km}$ for the Weichselian glaciation event and $100 \mathrm{~km}$ for the recent

569 glaciation event.

571 Figure 6: Horizontally averaged upper mantle viscosity profiles of the upper mantle for the

572 Weichselian glaciation event and the recent glaciation event for melt contents of 0 and $4 \%$ in 573 a dry upper mantle for a normal mid-ocean ridge scenario (A) and for excess temperatures of $574100{ }^{\circ} \mathrm{C}$ and $200{ }^{\circ} \mathrm{C}$ (mantle temperature of $1500{ }^{\circ} \mathrm{C}(\mathrm{B})$ and $1600{ }^{\circ} \mathrm{C}(\mathrm{C})$ ) due to additional 575 plume activity (averaged for each depth accros the section of the upper mantle under the 576 Weichselian and recent glaciation). The profiles show averages for each depth of all the 577 viscosities present underneath the Weichselian and recent glaciated areas. D) Comparison of 578 viscosity profiles for the different temperature regimes in the absence of melt.

Figure 7: Viscosity distribution under Iceland for a dry, melt-free upper mantle at excess tenperatures of $100{ }^{\circ} \mathrm{C}$ and $200{ }^{\circ} \mathrm{C}$ (mantle temperatures of $1500{ }^{\circ} \mathrm{C}$ and $1600{ }^{\circ} \mathrm{C}$ ) due to 582 additional plume activity.

584 Figure 8: Elastic thickness (A and C) and mean upper mantle viscosity (B and D) for Iceland 585 for a dry upper mantle during the Weichselian (A and B) and recent glaciation events (C and D) for a normal mid-ocean ridge scenario and excess temperatures of $100{ }^{\circ} \mathrm{C}$ and $200{ }^{\circ} \mathrm{C}$ (mantle temperatures of $1500{ }^{\circ} \mathrm{C}$ and $1600{ }^{\circ} \mathrm{C}$ ) due to additional plume activity.

Figure 9: Mean lithospheric thickness (mean of all thicknesses under the glaciated areas) and mean upper mantle viscosity (mean of all viscosities under the glaciated areas during the

591 Weichselian and recent glaciation events of Fig. 5 and 7) for various mantle temperatures at 592 the base of the modelled upper mantle in a dry and wet $\left(\mathrm{C}_{\mathrm{OH}}=100 \mathrm{H} / 10^{6} \mathrm{Si}\right)$ upper mantle. 
594 Figure 10: Compilation of lithospheric thickness and upper mantle viscosity estimates for

595 Iceland from glacial isostatic adjustment studies, seismology and the rheological modelling of 596 this study. 

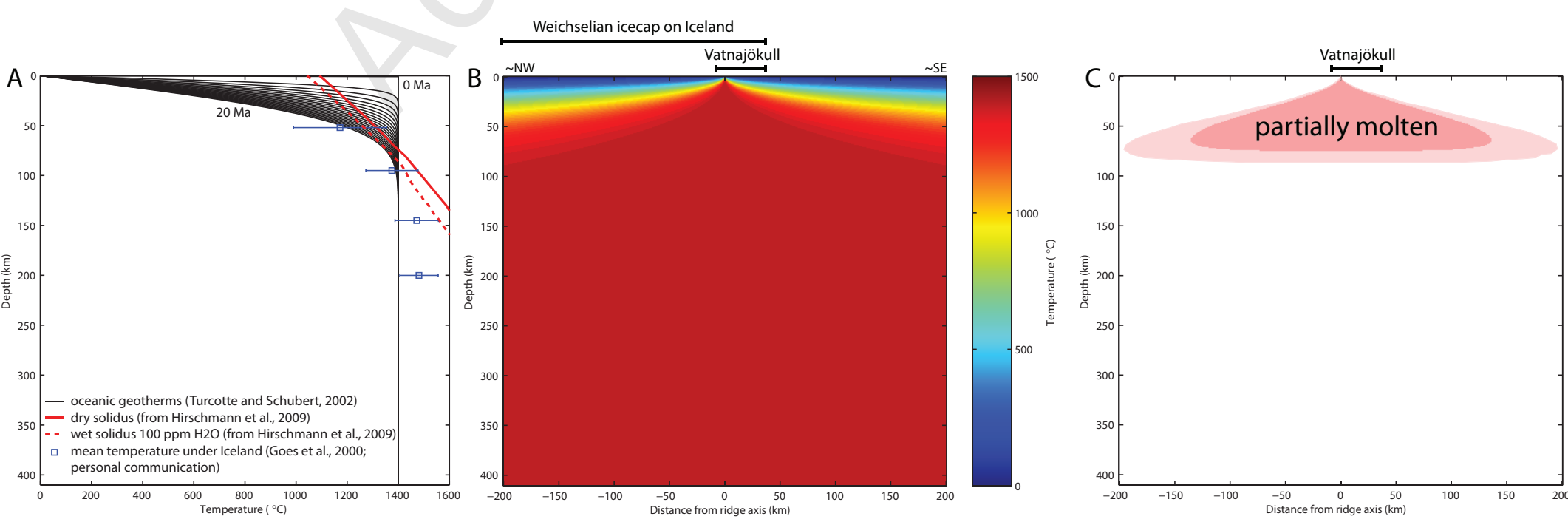

Page 27 of 36

Barnhoorn et al., Fig. 1 


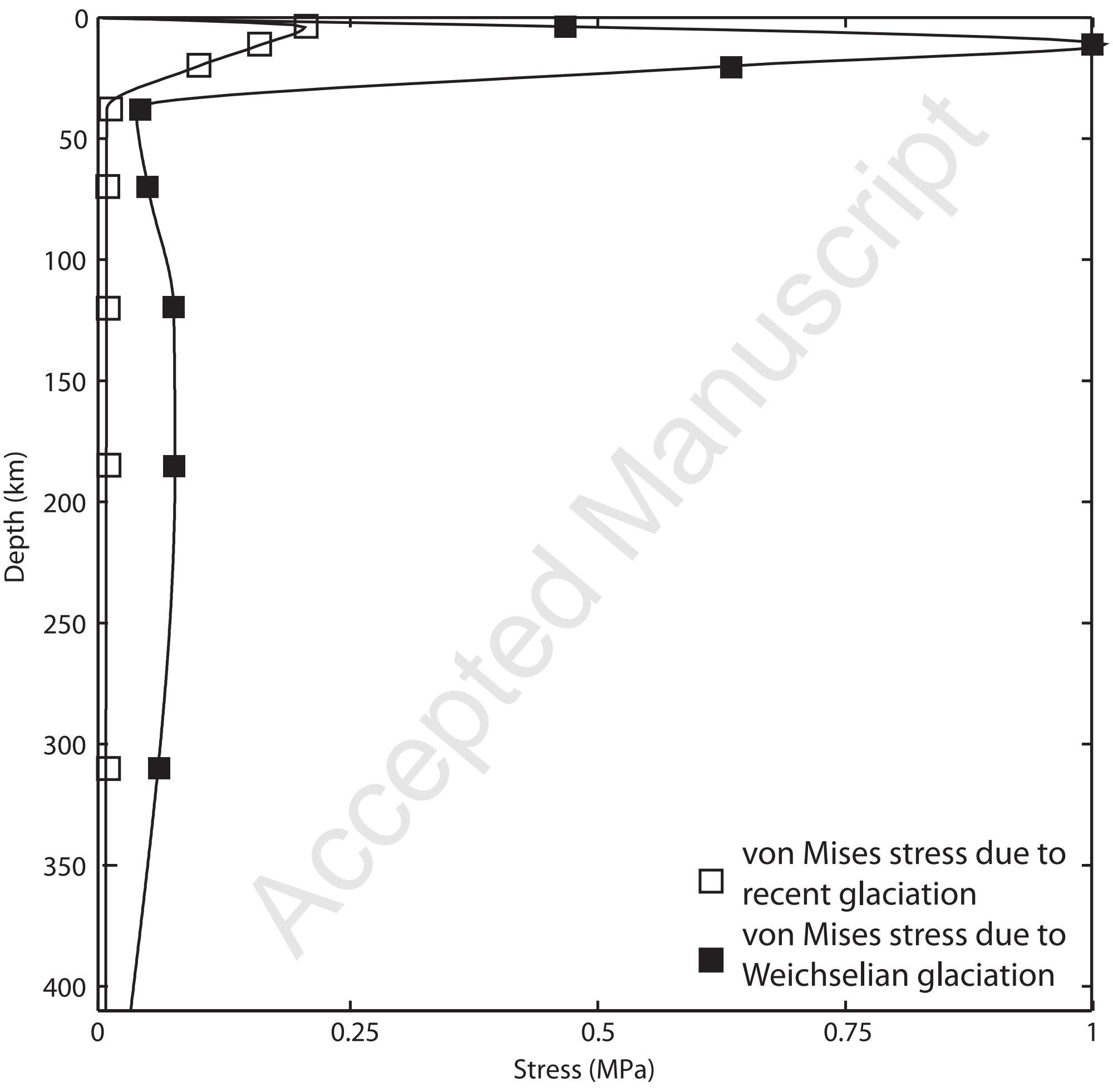

Barnhoorn et al., ${ }^{\text {Pafezgofige }} 2$ 

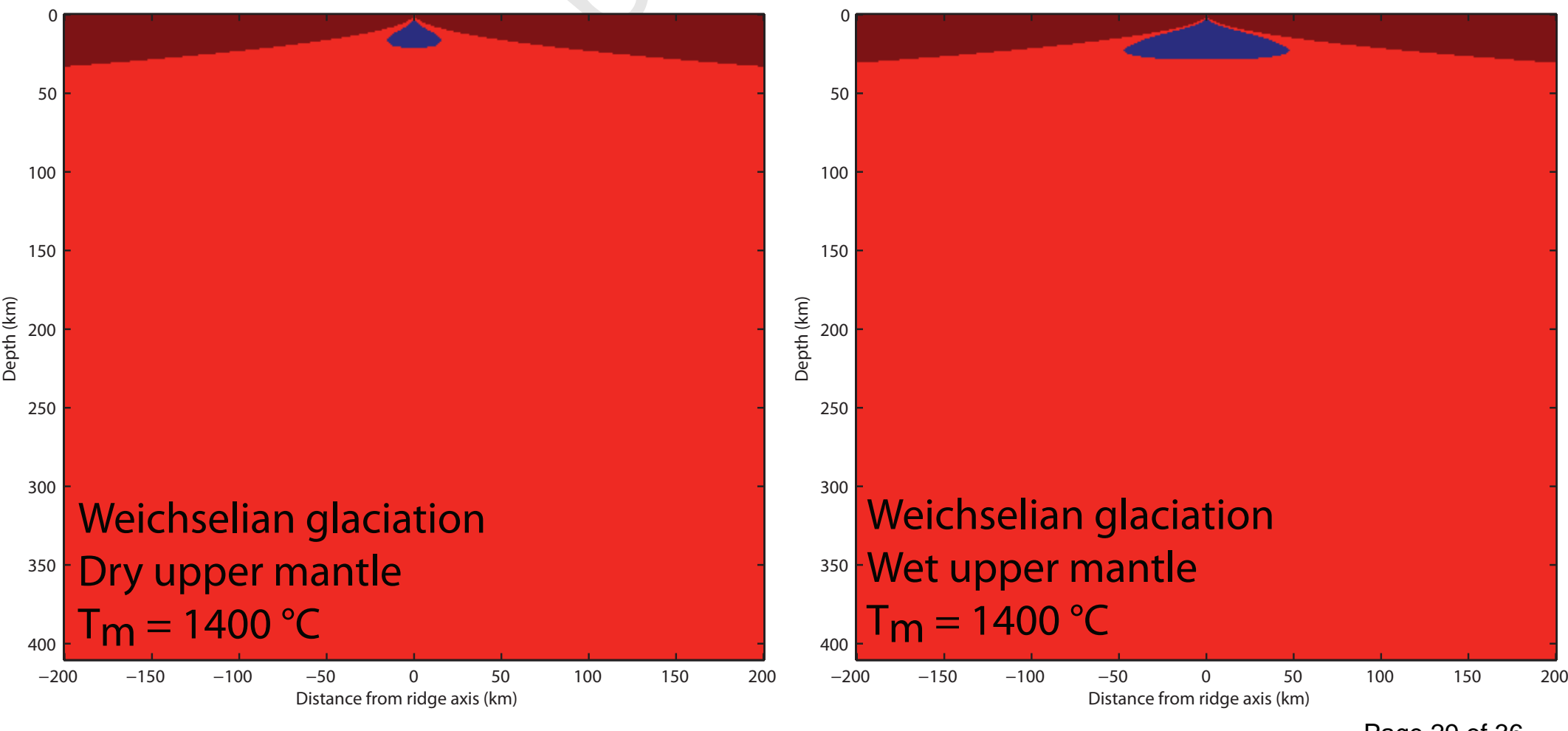

Page 29 of 36

Barnhoorn et al., Fig. 3 

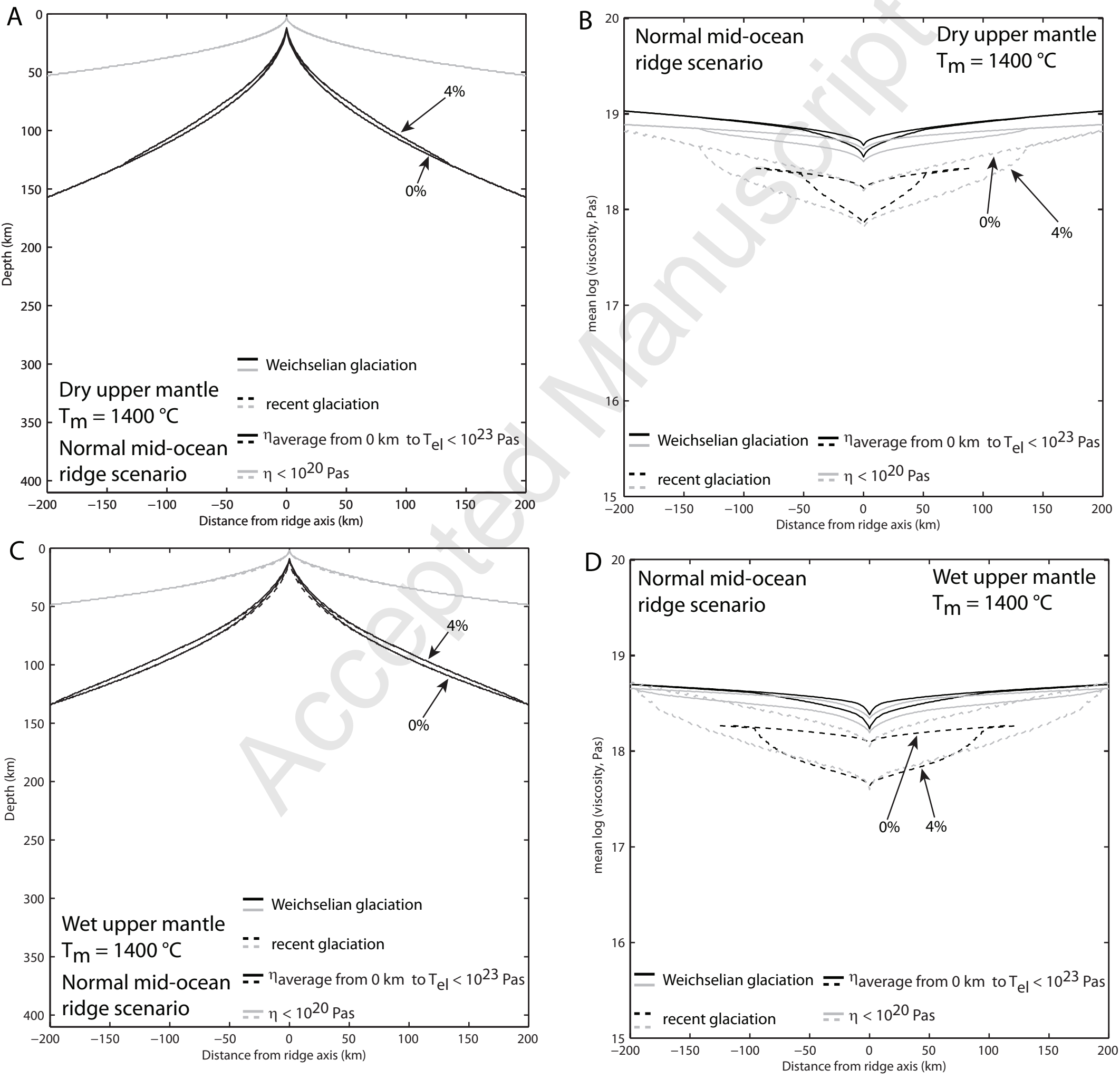

Page 31 of 36

Barnhoorn et al., Fig. 5 

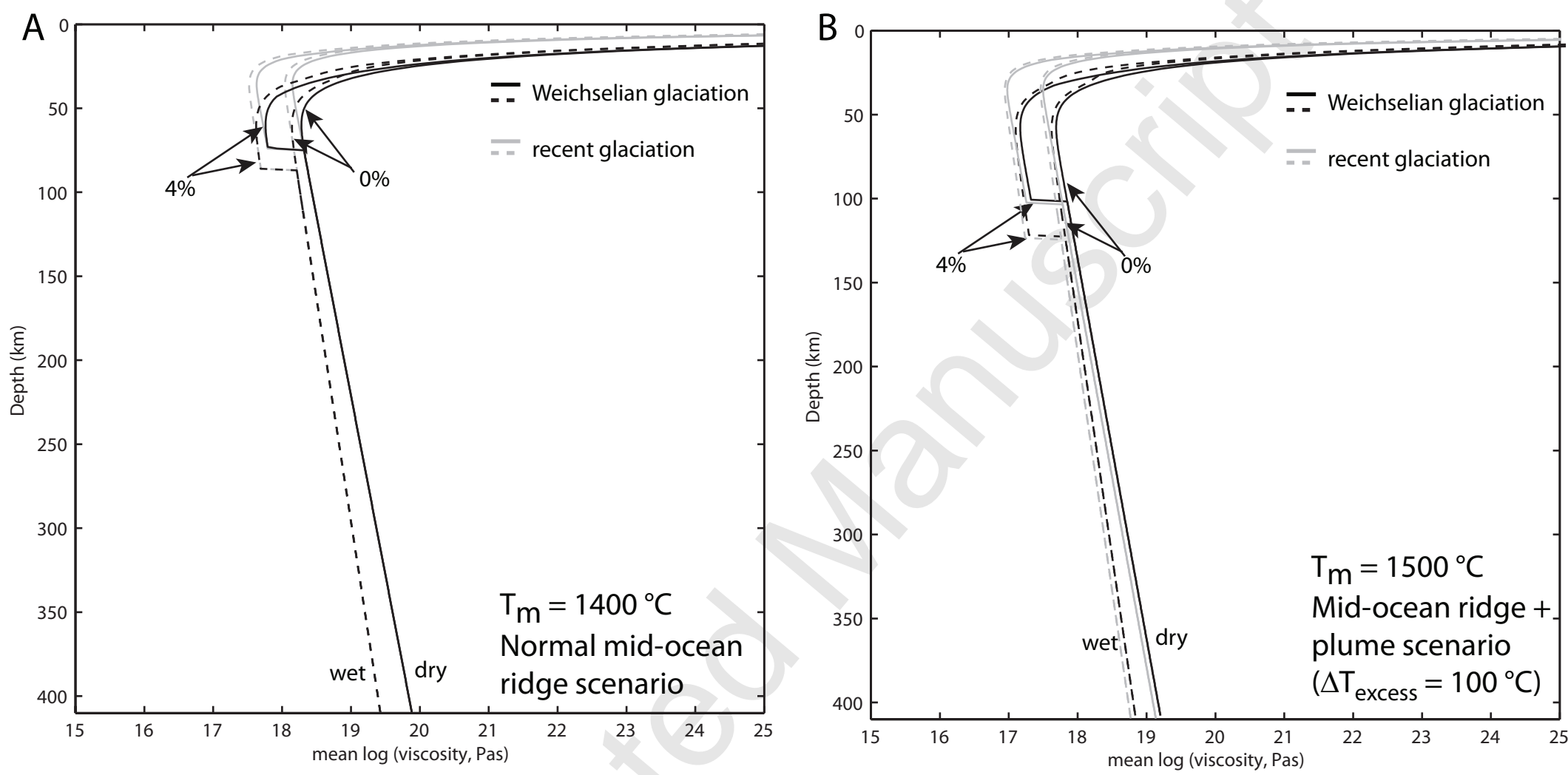
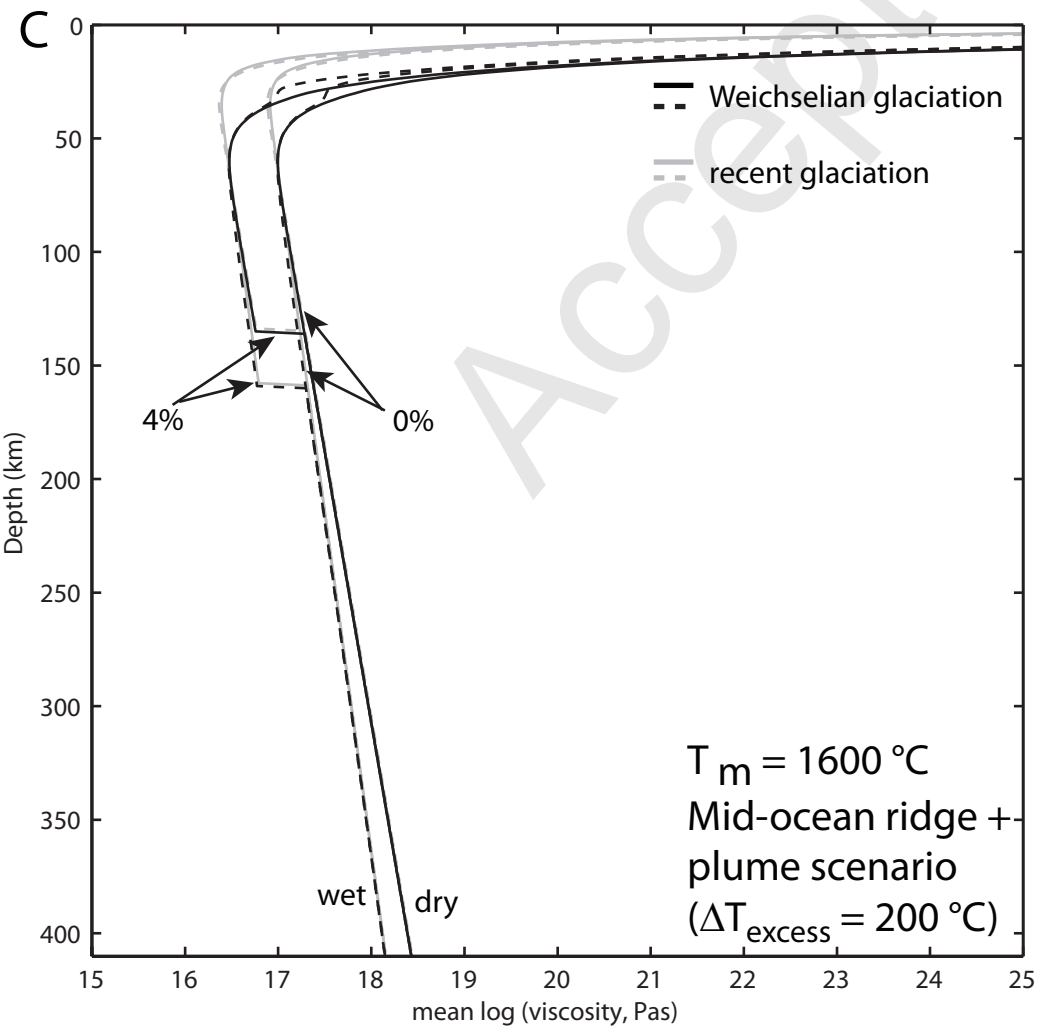

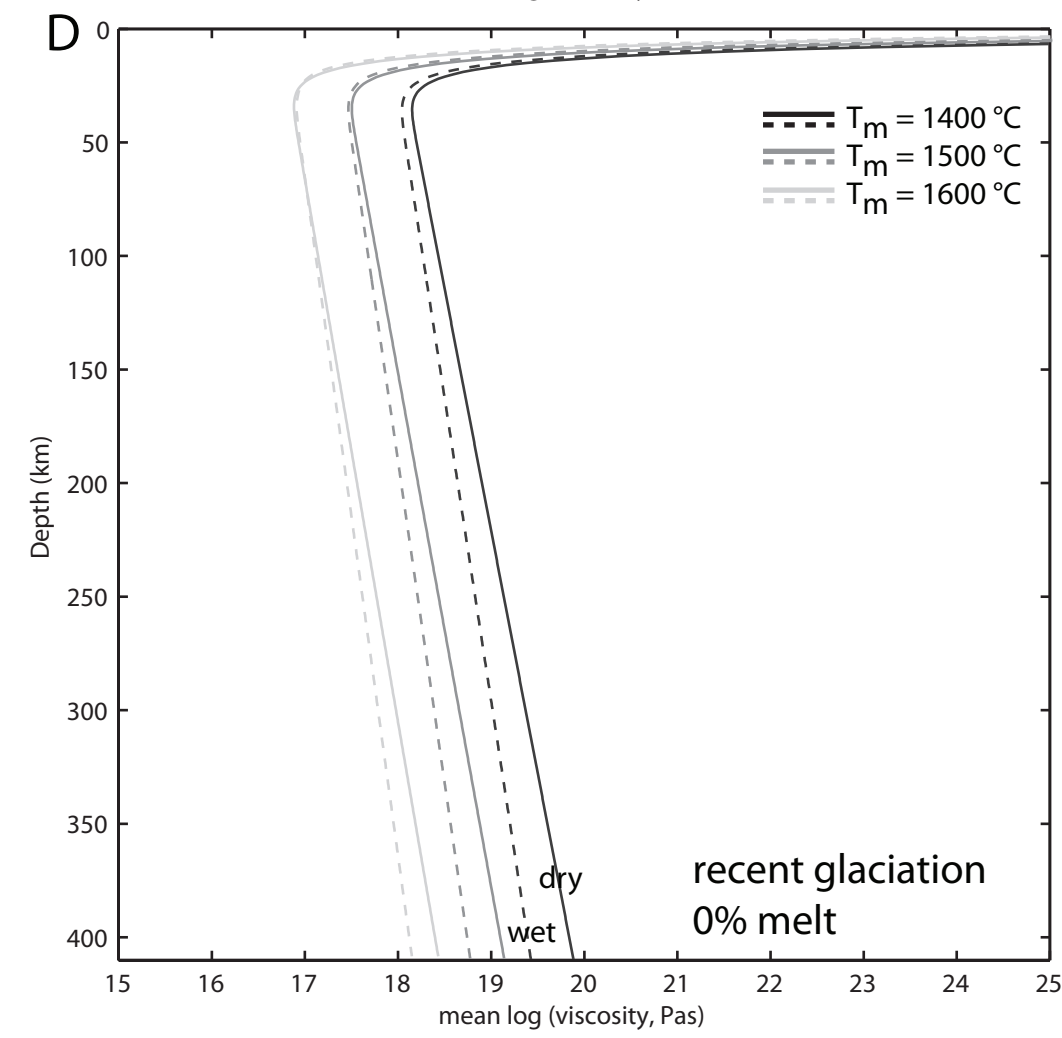

Page 32 of 36 

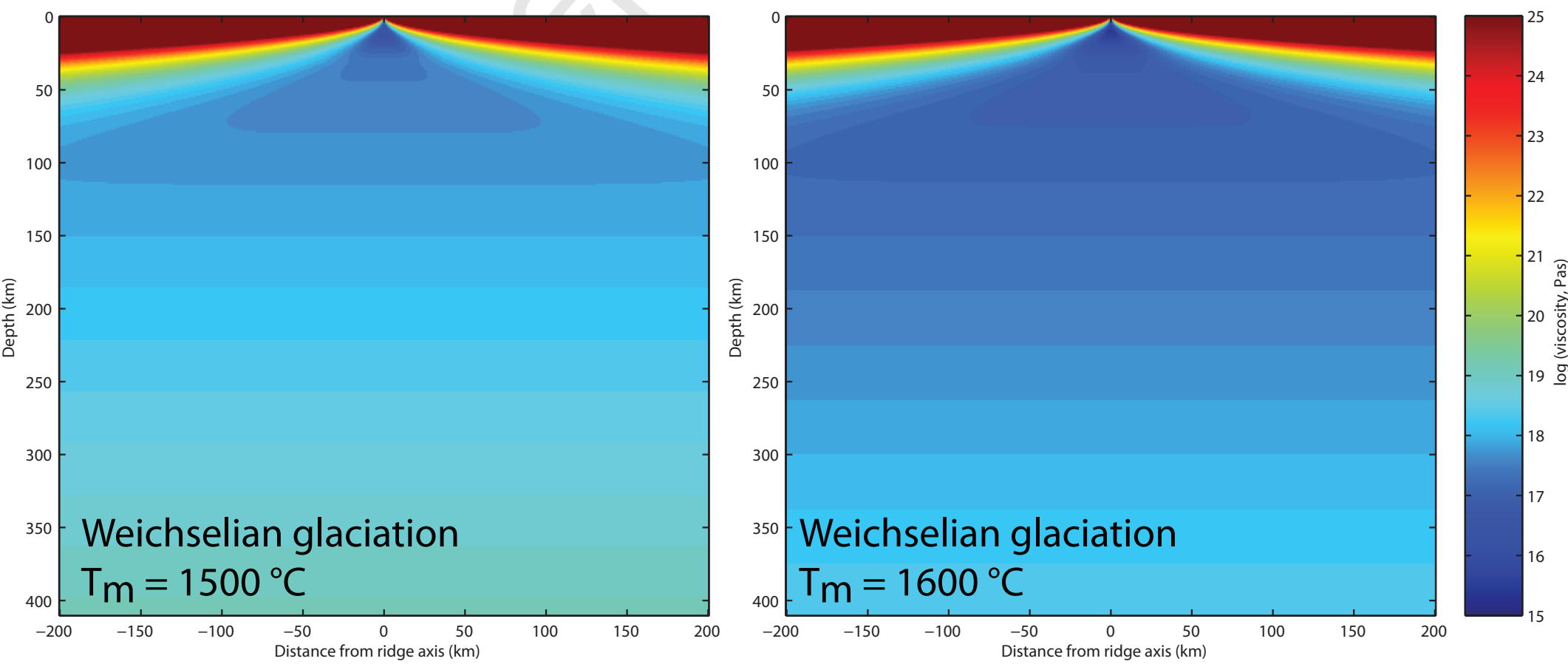

Page 33 of 36

Barnhoorn et al., Fig. 7 

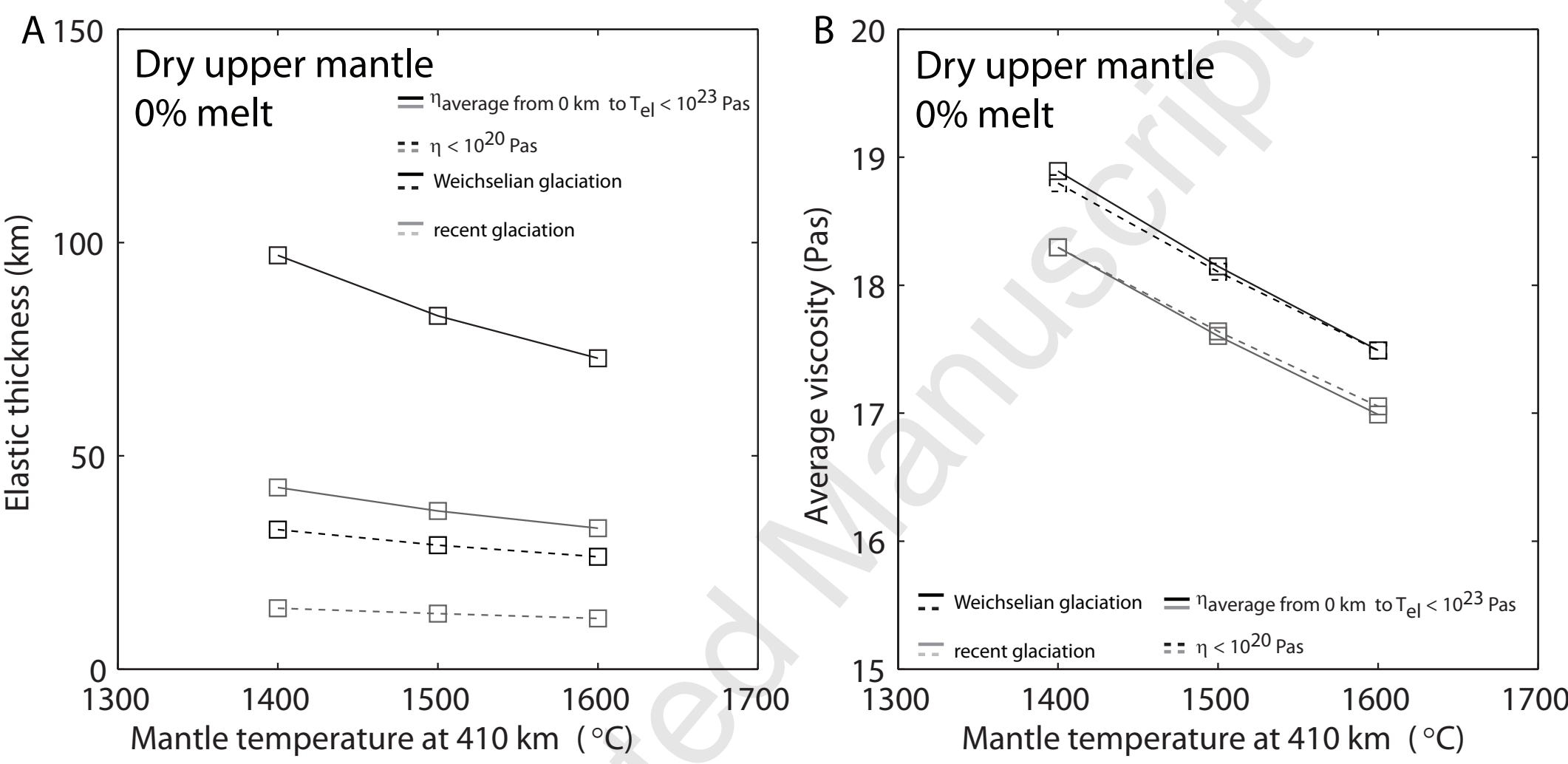

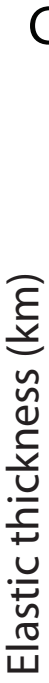

Wet upper mantle

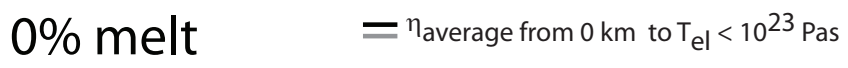

$==\eta<10^{20}$ Pas

-- Weichselian glaciation

$=$ recent glaciation

100

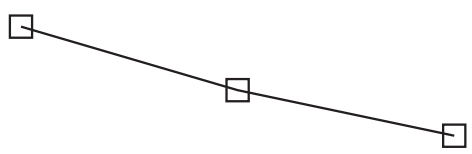

50

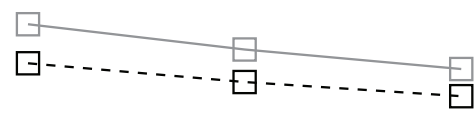

0

1300
1400

1500

1600

1700

Mantle temperature at $410 \mathrm{~km}\left({ }^{\circ} \mathrm{C}\right)$

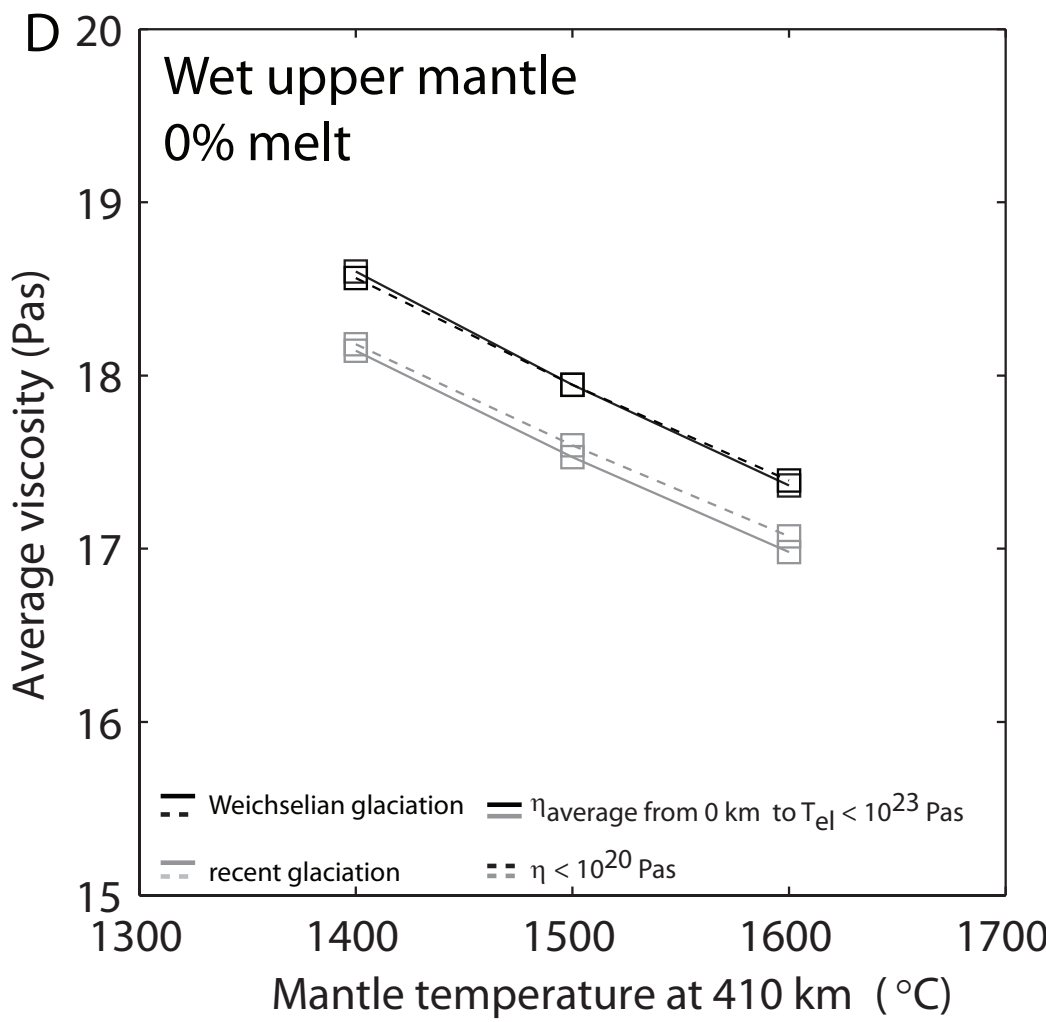

Page 35 of 36

Barnhoorn et al., Fig. 9 
elastic lithosphere thickness under Vatnajökull glacier (km)

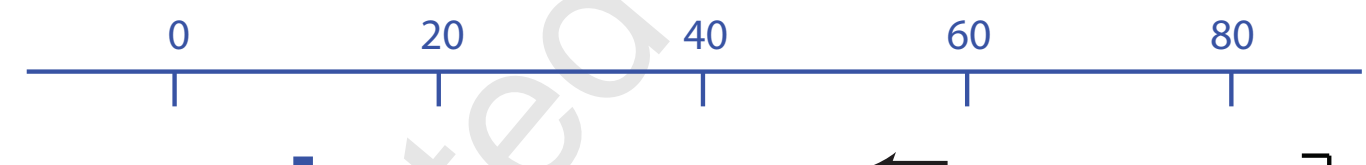

Sigmundsson (1991)

Sigmundsson and Einarsson (1992)

Biessy et al. (2008)

Le Breton et al. (2010)

Sjöberg et al. (2004)

Fleming et al. (2007)

Pagli et al. (2007)

Árnadóttir et al. (2009)

Kaban et al. (2002)

Kumar et al. (2005)

Weichselian glaciation

Recent glaciation

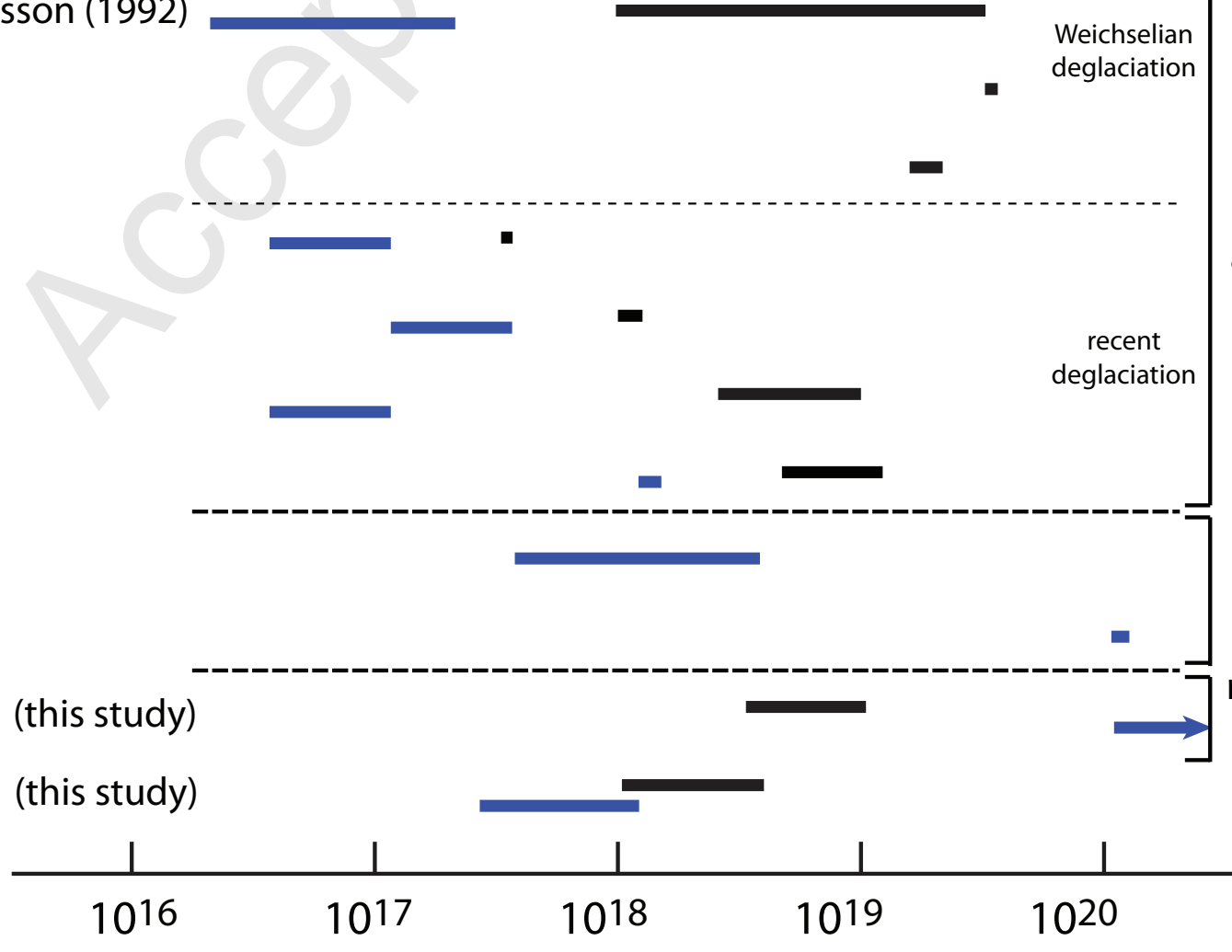

glacial isostatic adjustment

seismology rheological modelling

upper mantle viscosity under Vatnajökull glacier (Pas)

Barnhoorn et al, Fig. 10 